\title{
Corruption, Poverty and Economic Performance: Eastern Europe and Central Asia (ECA) Countries
}

\author{
Asst. Prof. Dr. Mustafa Ildırar (Çukurova University, Turkey) \\ Asst. Prof. Dr. Erhan İşcan (Çukurova University, Turkey)
}

\begin{abstract}
Corruption, defined as "the misuse of public power for private benefit." The World Bank describes corruption as one of the greatest obstacles to economic and social development. It undermines development by distorting the rule of law and weakening the institutional foundation on which economic performance depends. In past decades, many theoretical and empirical studies have presented corruption hinders investment, reduces economic growth, restricts trade, distorts government expenditures and strengthens the underground economy. In addition, they have shown a strong connection between corruption and poverty and income inequality. On the other hand, the literature on corruption points to the conclusion that corruption by itself does not lead to poverty. Rather, corruption has direct consequences on economic and governance factors, intermediaries that in turn produce poverty. Although corruption is seen in many countries in the world, it is higher and widespread in developing countries. This study investigates relation between corruption, poverty, and economic performance by using a panel consisting of countries in the Eastern Europe and Central Asia countries. It was shown that corruption affected directly economic performance and low economic performance leads to poverty. Additionally, results imply that rules against corruption could affect economic growth indirectly through their impact on the level of corruption.
\end{abstract}

\section{Introduction}

The term "corruption" can be identified and classified in several ways, since it contains types of human actions, as it is explained "as the misuse of entrusted power for personal or private gain" by World Bank (WB, 2007), whilst "the abuse of public or private office for personal gain....the active or passive misuse of the powers of public officials for private financial or other benefits" (by OECD, 2008). On the other hand, it can be seen that corruption is considered "misuse of entrusted power for private gain. It hurts everyone who depends on the integrity of people in position of authority" by The Transparency International (TI).

There are many types of corruption. The most widely known is bribery. The other types of corruption include fraud, embezzlement, nepotism, extortion, and kickbacks. On the other hand, categorization of the term corruption in a variety of ways facilitates the perception of its influence on economic performance, as the most featured categories are listed below:

\section{Supply versus Demand Corruption}

Having both "demand" and "supply" aspects, the term is used to define proposal of an illicit pay or anomalous benefit on supply aspect, whilst on the demand aspect it defines accepted or exacted a direct or indirect pay by the state employees.

\section{Conventional versus Unconventional Corruption}

The situation when government authorities misuse its powers in an illegal way to abuse state agency for personal benefit arises "conventional corruption", while an "unconventional" one arises from the making decisions disregarding public welfare by elected civil servants, such as abuse of confidence, pilferage, defalcation, and breach of trust. The conventional corruption is divided into two sub-categories, namely "grand" and "petty", which contains considerable amount of money and actions of top-level authorities, such as presidents, prime ministers, members of senate of parliament, and relatively smaller amounts and up and midlevel officials, respectively.

\section{Administrative versus Political Corruption}

Administrative corruption refers to actions of mid-level officials, arise from receive money and gift, etc. from individuals and companies, in return for policy implements, such as granting of a license in spite of being ineligible. Besides, political corruption is sometimes considered to be a grand one, as it arises from the actions of top-level authorities of executive, legislative and judiciary branches.

\section{Public versus Private Corruption}

While a state official is a party in a corrupt action refers to "public corruption", if any of private sector staff, from an ordinary employee to manager, takes part in an action within a private sector, such as being effective and influential by using certain power on fulfill of a duty or responsibility, it is called "private corruption" (Argandona,2003). 


\section{Systemic (Endemic) versus Occasional (Incidental) Corruption}

If a corrupt action is considered to be an integrated and fundamental course of political, social and economic system, in which being honest is deemed irrational, we can make a mention of a "systemic corruption". Although this action arises in irregular forms and in conditions, it can also have negative effects on morale and economic resources (Igwe, 2012).

\section{Centralized versus Decentralized Corruption}

Centralized corruption shows more estimative path than the decentralized one, thus it decreases the uncertain processes and misjudgments. However, if the transactions are not coordinated within the public administration, it can be suggested that the decentralized corruption will predominate (OECD, 2015).

On the other hand, the fact that the concept 'poverty' is a complex one requires extensive policies aimed at poverty eradication. Due to its sophisticated and complex nature, it is quite difficult to define poverty. Moreover, researchers with differing visions of world approach to this concept from diversified angles, and therefore reaching an agreement on its definition becomes much more troublesome. Some of the researchers consider the poverty as a consequence of imbalances of wealth and power, as caused by the structure and functioning of the prevailing system, while some others define the poor as a group of people who are not able to take advantage of the opportunities they get by virtue of lack of education and of personal skills such as competence, capability and personal qualifications. No matter how it is defined, it is clear that almost half of the world population lives in poverty, of whom 1 billion are children and 29.000 children, die of starvation every day. Poverty, in local terms, originates in a variety of reasons including unfair distribution of income, unemployment, inflation, rent economics, natural disasters, globalizations, etc. However, one of the important factors leading to poverty or impeding alleviation of the same is poverty. Fighting against poverty requires combating the corruption. In fact, there is an interrelation between these two variables. As a matter of fact,

- Corruption is a cause of poverty and impedes alleviation of poverty;

- Poverty is a cause of corruption and impedes combating the corruption;

- Corruption and inequality, one of its potential consequences, would become inevitable in the societies governed by the authorities that do not negotiate with the public opinion while establishing policies and budgets and that do not follow the principle of accountability;

- Notably in the poorest countries, successful outcome can be obtained if and only if a simultaneous fight is organized against poverty and corruption, thanks to which a coordinated struggle can be ensured (Erkan and Kara, 2007).

Poverty is an ongoing awaiting people's help from around the world. This issue is especially severe in developing countries. The region of ECA consists of 19 countries with the total population of about 380 million people, of whom 19.6 percent live below the national poverty line. Today corruption is the main obstacle for the development in ECA countries for the some organizations such as WB, IMF, UN. Because of corruption, ineffective distribution of welfare causes poverty and inequality.

There are a few studies, which research causal relationship between corruption and poverty especially for ECA countries. This study is intended to fill this gap in this area. We are concerned with the effects of corruption on economic performance and the consequences for the poverty in Eastern Europe and Central Asia (ECA) countries.

\section{Theoretical Framework and Some Empirical Findings from the Literature}

Studies on corruption's effect on economic performance have been increased rapidly since early 1990s. The debate on whether corruption has direct effect on poverty has led to two types of models. First, one is "Economic Model", the other one is "Governance Model". Economic model argue that corruption causes to poverty through by damage market conditions, disrupt competition, reduce domestic and foreign investment, increasing the cost of doing business and increasing income inequality. On the other hand, governance model claimed that corruption affect poverty by the channel reducing governance capacity such as hinders governance practices, reduces the services that are provided by the government, and reduces the credibility of the rule of law. In addition, corruption affects the institutional and infrastructure improvement negatively. This is especially observed in the health and education sectors.

The channels through which corruption lower economic performance and cause poverty, have been examined with different perspectives. All of these channels can be summarized in the following way (Gupta et.al.,1998; Rose-Ackerman,1997; Chetwynd et. al., 2003):

a. Lower economic growth rates-corruption impedes economic growth by deterrence for foreign and domestic investment, discouraging doing by business, decreasing direct or indirect tax revenues, , leading to violation of property rights

b. Hits the poor hardest-poor receive smaller share in economic growth because of corruption. It causes income inequality, destroy market competition, and also affect small sized firms 
c. Damaged access to public services-corruption impairs access and quality of public services, increase cost of basic public services to the poor, especially education and health sector and it lower quality of public services

d. Lower social services - corruption distorts the allocation of public expenditures, social services gets smaller share of budget, poor targeting social programs

After 1990s, most of the empirical studies on this topic presents that corruption has a negative impact on the economic performance of countries is emphasized. A large part of empirical studies proofed that there is a negative relationship between corruption and economic performance indicators such as growth rate of gross domestic products (GDP), GDP per capita, Consumer Price Index (CPI), labor productivity, etc. In other words there is broad consensus on the cost of corruption on economic performance. This negative relationship called in literature as "sand the wheels hypothesis". Some of the empirical studies that support this hypothesis can be summarized in the following way.

Firstly, Mauro (1995) who is the leader of the econometric studies of the effect of corruption on economic growth and investment across countries. He is finding that a significant negative relationship between corruption and the average annual economic growth rate for 1960-85 period. Rahman et al. (2000) test the relationship between the corruption and average per capita growth rates for 1990-97 for Bangladesh. They find that an increase of corruption by one standard deviation reduces economic growth by $0.79 . \%$. Mo (2000) analyzed the effect of corruption on economic growth and its transmission channels such as the investment, human capital, and political stability. He found that a one-unit increase on the corruption index leads to reduce growth rate by $0.54 \%$. Of this effect, $53 \%$ is explained by the effect of corruption on political instability, and, in turn on economic growth. Dreher and Herzfeld (2005) investigate economic cost of corruption that a \%1 increase in corruption index reduces economic growth by $0.13 \%$. Their estimate includes indirect effect through government expenditures, investment, foreign aid and inflation as well as the direct effect of corruption on growth. Gyimah and et al. (2006) uses panel data and research the effect of corruption on growth for some OECD, Latin American, and Asian Countries. They assert that $10 \%$ decrease in corruption increases the growth rate of income by about $1.7 \%$ in OECD and some Asian countries, $2.6 \%$ in some Latin American countries, and by $2.8 \%$ in some African countries. Swaleheen (2011) analyzed relationship between economic growth rate and corruption with the cross-country dynamic panel data regression analysis for the 1984-2007 period. He concluded that a one standard deviation increase in corruption reduces economic growth rates by $0.12 \%$. According to the results obtained by Algan and et. al. (2014), which was conducted on corruption-economic growth relationship of the Turkish Economy for the period 1980-2011 by using vector error correction model, corruption conducted by those with low level of education has a negative impact on growth, whereas corruption diminishes the level of education rises. Because of this phenomenon, a positive relationship between corruption and economic growth is brought forward in the light of elementary school and higher education graduates who were sentenced of corruption.

However, corruption's effect on economic performance remains still unclear, and studies has a different results across different countries, region and the periods. Some former economist such as Leff (1964), Huntington (1968), Leys (1970), Lull (1985) etc. claimed that corruption has a positive effects on economic performance of countries which governed weakly and less institutional quality by the facilitates doing by business, promotes efficiency, overcome bureaucracy. This approach is called such as "greasing the wheels hypothesis". Some of empirical studies support this hypothesis. (Vaal and Ebben, 2011; Mendez and Sepulveda, 2006; Egger and Vinner, 2005, Meon and Weill, 2010 etc.). In addition, the argument that there is a positive correlation between corruption and economic growth in some Asian Countries (called Asian Paradox ) is supported by the many empirical studies. (Capmpos,et. al., 2010). On the other hand, there is some empirical studies emphasized that there is no relationship between corruption economic growth. According to Drury et al. (2005) corruption has no significant effect on economic growth rate in democratic countries while it hurts economy in non-democratic countries. In other study, Aidt (2009) conclude that no effects of corruption on GDP growth rate while strong inverse relation with real wealth per capita.

\section{Corruption Effects on Economic Performance of ECA Countries}

Academic research and studies are suggesting that corruption is a negative influence on some macroeconomic indicators such as domestic and foreign investment level, employment level, economic growth rate, per capita income, international trade volume and price stability. In addition, corruption distorts market mechanism prevents fair competition and cause shadow market and inefficient allocation resources. On the other hand, although there are many causes of poverty, are being affected by these indicators by directly or indirectly.

The cost of corruption is quite high for global economy, private companies, and people in the world. According to latest data of World Bank, this cost at a macro level, more than $5 \%$ of global GDP. In addition, it adds unnecessary cost of doing business by $10 \%$. Furthermore, countries with high level of corruption have a one third of average income of low corruption countries. 
Poverty is a very complex theme in ECA countries where 80 million people live on less than $\$ 5$ per day and try to meet even basic needs. Unemployment and low wages rates are seen as major contributors to poverty. However, corruption is seen as indirect contributors to poverty. Poverty is still main obstacle for development in ECA countries at the national levels shows disparities. However, the figure concludes that there is a declining trend in poverty except 1990s.

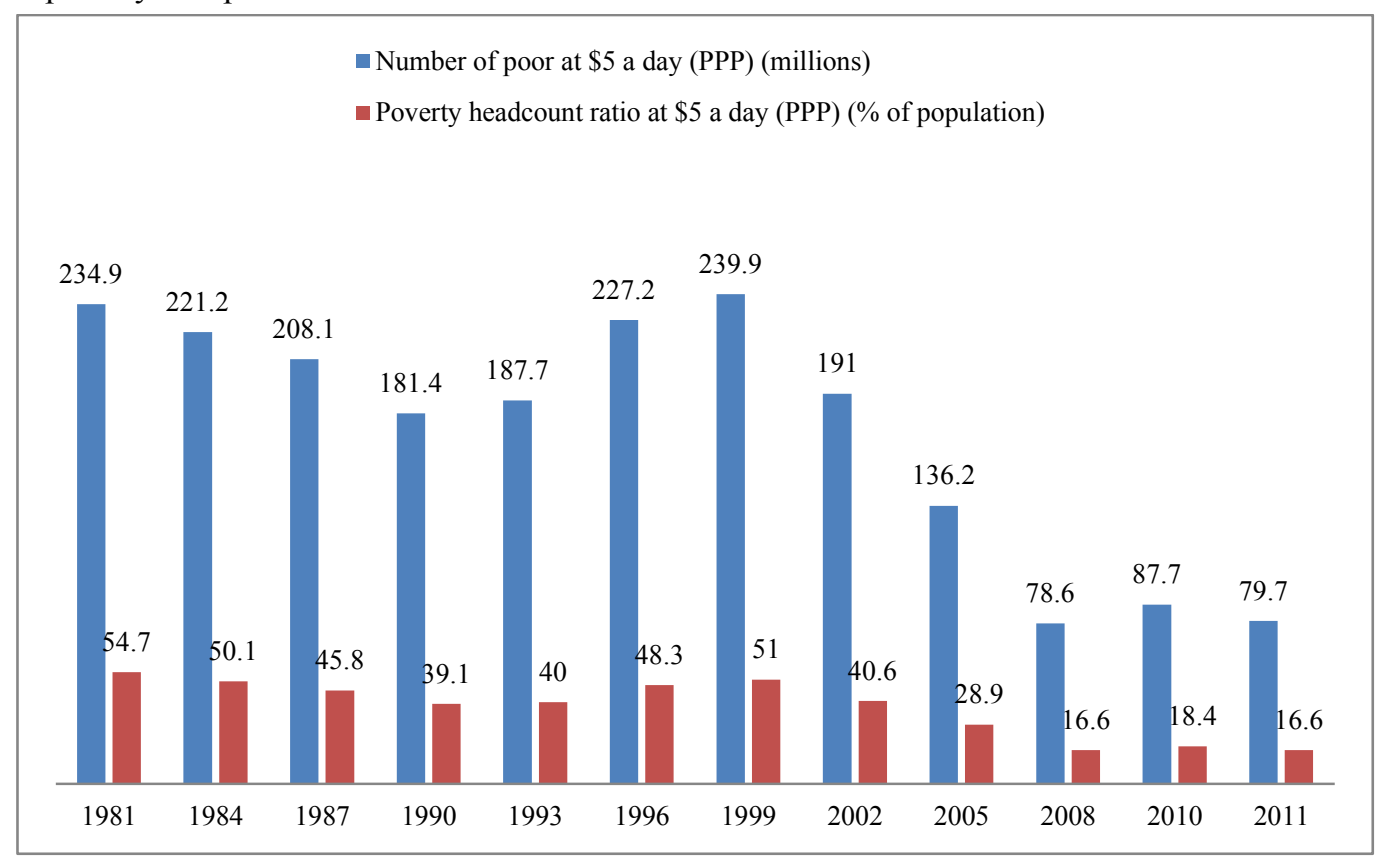

Figure 1. Poverty Trends in ECA Countries Resource: WB, IMF Poverty Indicators

Despite significant progress occurring in ECA countries since early 1980s, the figure shows concerning poverty in the ECA region. The data show disturbingly very high poverty levels in ECA region even in some upper middle-income countries.

The corruption perceptions index (CPI), which is announced by the Transparency International, the institution making important researches about corruption, sorts 175 countries by the level of perception over corruptions committed in the public sector. Covering expert assessments and opinions from the business world, Corruption Perceptions Index (CPI) is considered as one of the leading global indicators for corruptions in the public sector. The CPI currently ranks 175 countries "on a scale from 100 (very clean) to 0 (highly corrupt). We see that $95 \%$ of ECA countries score below 50 out of 100 while global average score is 43 .

In Economist, study shows that in countries ranked below 40 on the Corruption Perception Index (CPI) meaning the most corrupt countries, the correlation is quite weak but there is a strong connection between higher levels of human development and lower levels of perceived corruption for the countries scoring above 40 on the CPI. There are some disparities in CPI values. Uzbekistan, Turkmenistan, Tajikistan has a lowest CPI-1n other words-most corrupt countries in the region, while Georgia, Macedonia and Turkey is the highest value of CPI. Tajikistan also with the lowest level of per capita GDP in ECA countries.

Countries which ranked below 40 on the CPI such as Armenia, Bosnia\&Herzigova, Inflation rate in Armenia averaged 719.90 percent from 1993 until 2015, this is the highest ratio in ECA countries. On the other hand, Bosnia\&Herzigova has a worst performance in employment level in ECA countries. Unemployment rate in Bosnia\&Herzigova averaged 43.13 percent from 2007 until 2015. In addition, the poverty headcount ratio (HCR) at national poverty line (\% of population) in Tajikistan is 85.1 . It notes that income poverty remains serious problem in former Soviet republic not only Tajikistan. In Armenia, Georgia and Kyrgyzstan more than thirdquarter of population live in extreme poverty.

Some empirical studies demonstrates that the correlation between poverty levels and control of corruption is relatively weak but it is reinforced by strong correlation between control of corruption and GDP per capita, and Human Development Index, as well as between control of corruption and the levels of poverty. Briefly, the correlation between poverty levels and the control of corruption is relatively weak but it is reinforced by the strong correlation between control of corruption and GDP per capita. The control of corruption is 4.3 out of 100 , Turkmenistan only ranked in the 4.th percentile for control of corruption, lower than ECA average of 43.7. After Turkmenistan, Uzbekistan is not only the control of corruption, but also lowest value of GDP per capita. 


\begin{tabular}{|c|c|c|c|c|c|c|c|c|}
\hline Country & $\begin{array}{c}\text { Gross } \\
\text { National } \\
\text { Income } \\
\text { Per } \\
\text { Capita } \\
(2011) \\
\text { \$-PPP }\end{array}$ & $\begin{array}{l}\text { Annual } \\
\text { Average GDP } \\
\text { Growth Rate } \\
\text { (\%) Time } \\
\text { Period }\end{array}$ & $\begin{array}{c}\text { Averaged } \\
\text { Unemployment } \\
\text { Rate (\%) } \\
\text { Time Period }\end{array}$ & $\begin{array}{c}\text { Averaged } \\
\text { Inflation } \\
\text { Rate (\%) } \\
\text { Time Period }\end{array}$ & $\begin{array}{c}\text { Human } \\
\text { Development } \\
\text { Index } \\
\text { (HDI)/Rank } \\
\text { (2013) }\end{array}$ & $\begin{array}{l}\text { Head } \\
\text { count } \\
\text { Ratios } \\
(\text { HCR) } \\
\text { (\$5/day } \\
\text { below) } \\
(2012)\end{array}$ & $\begin{array}{c}\text { Corruption } \\
\text { Perception } \\
\text { Index/Rank } \\
(\mathbf{2 0 1 4})\end{array}$ & $\begin{array}{c}\text { Control of } \\
\text { Corruption } \\
\text { (World } \\
(2013) \\
\text { out of } 100\end{array}$ \\
\hline Albania & 9.225 & $5.08(96-14)$ & $15.07(93-15)$ & $3.22(95-15)$ & $0.716(95)$ & 47.5 & $33(110)$ & 25.84 \\
\hline Armenia & 7.952 & $7.81(96-14)$ & $10.97(98-15)$ & $719.9(93-15)$ & $0.730(87)$ & 79.7 & $37(94)$ & 39.71 \\
\hline Azerbaijan & 15.725 & $11.2(01-15)$ & $6.83(00-13)$ & $7.01(07-15)$ & $0.747(76)$ & 40.4 & $29(126)$ & 18.66 \\
\hline Belarus & 16.403 & $2.29(11-15)$ & $1.73(95-14)$ & $278.5(92-15)$ & $0.786(53)$ & 6.3 & 31(119) & 37.32 \\
\hline Bos.\&Herz. & 9.430 & $1.18(04-15)$ & $43.13(07-15)$ & $1.06(11-15)$ & $0.731(86)$ & 3.8 & $39(80)$ & 52.15 \\
\hline Georgia & 6.889 & $4.37(06-15)$ & $13.56(98-14)$ & $7.88(96-15)$ & $0.744(79)$ & 77.9 & $52(50)$ & 66.51 \\
\hline Kazakhstan & 19.440 & $5.49(95-15)$ & $6.02(03-15)$ & $62.52(92-15)$ & $0.757(70)$ & 34.7 & $29(126)$ & 20.10 \\
\hline Kyrgyzstan & 3.021 & $3.93(94-15)$ & $2.89(00-13)$ & $8.45(03-15)$ & $0.628(125)$ & 79.0 & $27(136)$ & 11.48 \\
\hline Kosovo & 9.446 & $3.51(06-14)$ & $44.10(01-13)$ & $2.44(03-15)$ & $0.786(53)$ & 29.7 & $33(110)$ & 30.62 \\
\hline FRYMac & 11.744 & $3.28(04-15)$ & $31.63(93-15)$ & $2.30(06-15)$ & $0.732(84)$ & 34.8 & $45(64)$ & 59.33 \\
\hline Moldova & 5.041 & $3.24(96-15)$ & $6.58(00-15)$ & $6.83(07-15)$ & $0.663(114)$ & 45.4 & $35(103)$ & 23.92 \\
\hline Montonegro & 14.710 & $2.21(01-15)$ & $16.91(02-15)$ & $5.44(01-15)$ & $0.789(51)$ & 17.3 & $42(76)$ & 51.20 \\
\hline Russian Fed. & 22.616 & $3.51(96-15)$ & $7.93(93-15)$ & $140.9(91-15)$ & $0.778(57)$ & 10.7 & $27(136)$ & 16.75 \\
\hline Serbia & 11.300 & $2.87(97-15)$ & $19.45(08-15)$ & $7.33(07-15)$ & $0.745(77)$ & 15.1 & $41(78)$ & 50.72 \\
\hline Tajikistan & 2.424 & $3.36(92-15)$ & $2.43(00-15)$ & $13.91(99-15)$ & $0.607(113)$ & 85.1 & $23(152)$ & 10.5 \\
\hline Turkey & 18.391 & $3.88(99-15)$ & $9.88(05-15)$ & $36.67(65-15)$ & $0.759(69)$ & 21.9 & $45(64)$ & 61.7 \\
\hline Turkmen. & 11.533 & $5.91(94-14)$ & $10.89(91-13)$ & $12.89(97-14)$ & $0.698(103)$ & n.a. & $17(169)$ & 4.31 \\
\hline Ukraine & 8.214 & $3.06(00-15)$ & $8.56(03-15)$ & $42.35(92-15)$ & $0.734(83)$ & 6 & $26(142)$ & 11.96 \\
\hline Uzbekistan & 5.227 & $8.06(06-15)$ & $4.80(2012)$ & $4.33(06-14)$ & $0.661(116)$ & 16 & $18(166)$ & 8.13 \\
\hline
\end{tabular}

Table 1. Economic Performance and Corruption Relationship in ECA Countries Source: WB, IMF Poverty Indicators

\section{Model and Data}

This section defines variables and describes data. We collect a set of panel data from 16 of ECA countries over the period 2003-2014. The annual data is used in this study. The data ranging from 2003 to 2014 for all countries obtained from Transparency International, United Nations, and IMF International Financial Statistics (IFS) iLibrary system. The data's are as follows. Annual Corruption Perceptions Index (known as CPI but we use as COR) is the best-known corruption index. It ranks countries by their perceived levels of corruption, The Human Development Index (HDI) measures poverty with three areas: first, as a long and healthy life second, is knowledge and third, as standard of living. The HDI focuses on the "progress in a community as a whole" (United Nations 1997: 20). The HDI is a useful indicator to compare nations for poverty. Consumer Price Index (CPI) is a well-known macroeconomic indicator. We use CPI as a proxy for macroeconomic stability.

\subsection{Methods and Findings}

This paper examines the link between poverty, corruption, and macroeconomic performance. We use an econometric model to study this relationship. Our empirical test investigates whether; poverty is correlated with corruption and macroeconomic performance or not. With this aim, we analyze within some selected ECA countries using panel data and estimating the following model:

$$
y_{i, t}=\beta_{1} y_{i, t-1}+\beta_{2} \alpha_{i, t}+\beta_{1} \rho_{i, t}
$$

\subsection{Panel Unit Root Analysis}

Main issue before estimating the model is to test if the variables are stationary or not. We carry out panel unit root tests on the dependent and independent variables. We follow the approach of Levin, Lin \& Chu panel unit root test and Choi unit root test (Fisher PP). Results of this test applied on our time series in levels are reported in the table below. The lag length are chosen by the result of Schwarz Information Criterion and shown in the parenthesis. Table illustrates that all variables are stationary. 


\begin{tabular}{|l|l|l|}
\hline Variables & Levin, Lin \& Chu & Choi (Fisher PP) \\
\hline Individual Intercept & & \\
\hline HDI & $-14.9029^{* * *}$ & $-6.54471 * * *$ \\
\hline COR & $-4.66606^{* * *}$ & $-2.07940^{* * *}$ \\
\hline CPI & $-6.05969^{*}$ & $-3.57378^{*}$ \\
\hline Individual Intercept and Trend & & \\
\hline HDI & $-65.0860^{* * *}$ & $-3.50424 * * *$ \\
\hline COR & $-4.16852^{* * *}$ & $-3.97568^{* * *}$ \\
\hline CPI & $-2.78963 *$ & $-3.00440^{*}$ \\
\hline
\end{tabular}

Table 2. Results for panel unit root test. The choice of lag levels is based on the Schwarz Information Criterion. The LLC tests were computed using the Bartlett kernel with automatic bandwidth selection. ***, ** and * indicate significance at the $1 \%, 5 \%$ and $10 \%$ levels.

\subsection{Empirical Results}

We now proceed to estimate the dynamic model specified here which has the logarithm of HDI as the dependent variable. Table 2 presents GMM first difference estimates with corruption measured by the Corruption Perception Index by Transparency International and macroeconomic performance measured by consumer price index. The coefficients have the expected sign.

The coefficients for corruption and consumer price index are both significant. The negative and significant impact of corruption on poverty is consistent with the results of many empirical studies. These studies lend support "sand to the wheels" hypothesis. The positive and significant impact of consumer price index on poverty is an interesting result in our model. This suggests that higher consumer prices decreases poverty. In other words, an increase in prices will cause a decrease in poverty.

\begin{tabular}{|l|c|c|c|c|}
\hline Variable & Coefficient & Std. Error & t-Statistic & Prob. \\
\hline HDI(-1) & 0.3259 & 0.00408 & 79.750251 & 0.0000 \\
\hline COR & -0.0342 & 0.00746 & -4.584012 & 0.0000 \\
\hline CPI & 0.0373 & 0.00639 & 5.839725 & 0.0000 \\
\hline
\end{tabular}

Table 3. Results of Dynamic Panel Data Analysis. This table reports estimation results for the dynamic panel data model, estimated using the Arellano-Bond GMM estimation method.

Three diagnostic tests are run for validity of the empirical models. First, the Sargan test is used to identifying restrictions under the null hypothesis of the validity of the instruments (Arellano and Bond, 1991). The second test is proposed by Arellano and Bond (1991) and examines the hypothesis that the residual from the estimated regressions is not correlated at second order. Third test is the Wald test indicates the goodness of fit. All of the diagnostics tests run and results reported below.

\begin{tabular}{|l|c|}
\hline Diagnostic Tests & Test Statistics \\
\hline Hansen J-Statistics & 15.82867 \\
\hline Arellano-Bond test of $1^{\text {st }}$ order autocorrelation & -3.266144 \\
\hline Arellano-Bond test of $2^{\text {nd }}$ order autocorrelation & -1.551839 \\
\hline Wald chi2 (prob) & 0.0000 \\
\hline No. of observations & 192 \\
\hline No. of countries & 16 \\
\hline
\end{tabular}

Table 4. Diagnostic Tests

\section{Conclusion}

One of the most important conclusions to be drawn from empirical studies is that corruption, in itself, does not lead to poverty, rather it gives rise to poverty through indirect channels by affecting social-economic, political and administrative conditions. Corruption usually affects economic growth and thus affects employment levels and income distribution, which might to lead to poverty. In addition, corruption affects the quality of government services and the shape of public expenditures which mainly the poor.

In the mainstream literature, it is concluded that corruption has an effect on poverty. Our aim is to extend the literature by using a well-known dynamic panel data estimation method to test our model for ECA countries. We present evidence that corruption has a direct effect on poverty. In addition, our results show that consumer prices index -as proxy for macroeconomic performance- have positive effect on poverty. This result is expected but quite interesting. This positive effect shows that price increases means that demand-pull inflation is the sign of a reducing in poverty. There is a simple rationale behind this case. An increase in income will cause simply demand-pull inflation. This increase in income also affects Human Development Index, a decrease in poverty.

As a result, corruption has a significant effect on the poverty in ECA countries. If a country wants to decrease its poverty it should improve factors such as laws and controls, as well as good governance. 


\section{Acknowledgments}

This work was supported by Research Fund of the Cukurova University.

\section{References}

- Aidt, 2009. "Corruption, Institutions and Economic Development", Oxford Review Of Economy Policy, 25(2), p.292

- Algan, N. et. al. (2014)-“Toplumsal Bir Mesele Olarak Yolsuzluk ve Büyüme İlişkisi”, http://avekon.org/papers/996.pdf (01.07.2015)

- Arellano, M. and Bond, S. (1991). Some tests of specification for panel data: Monte Carlo evidence and an application to employment equations, Review of Economic Studies, 58, 277-297.

- Campos et all., 2010 "Whither Corruption? A Quantitative Survey of the Literature on Corruption and Growth", IZA Discussion Paper No:5334

- Castro et all, 2012. "Does Corruption Sand the Wheels in the Public Works Execution?", Economia Informale, Evasione Fiscale e Corruzione, Preliminary Draft

- Chetwynd et all., 2003 “Corruption and Poverty: A Review of Recent Literature”, Management Systems International, Final Report, Washington, DC.

- Dinçer and Günalp, 2008. "Corruption, Income Inequality, and Poverty in the United States”, $\underline{\text { FEEM }}$ Working Paper No. 54.2008.

- Diridi, 2013. "Corruption and Economic Growth: The Transmission Channels", Journal of Business Studies Quarterly, Volume 4, Number 4,p.121.

- Erkan,B., Kara, O. "Yolsuzluk ve Yoksulluk Göstergeleri Arasındaki İlişsi:Türkiye Örneği”, http://www.oguzkara.com/ypksulluk\%20yolsuzluk.pdf (01.07.2015)

- Gökçekuş et all.,2015. "Level and quality of openness and corruption in ECA coutries", Applied Economic Letters, June, p.37.

- Gupta et all., 1998. "Does Corruption Affect Income Equality and Poverty”,IMF Working Paper Series, WP:9/76

- Johnson et all., 2013. "Corruption, Regulation, and Growth: An Emprical Study of the United States", Econoomics Of Governance, Volume 15, Issue 1, p.51

- Kato and Sato, 2014. "Greasing the Wheels? The Effect of Corruption in Regulated Manufacturing Sectors of India", Kobe University, Research Institute for Economics and Business Administration, Discussion Paper Series:2014-07.

- Kibet, 2013, "Effect of budget deficit and corruption on private investment in developing countries: A panel data analysis", African Journal of Business Management, Vol.7 (27), p.2720.

- Knack and Kisunko, 2011. "Trends in Corruption and Regulatory Burden in Eastern Europe and Central Asia", The International Bank for Reconstruction and Development/The World Bank

- Meon and Sekkat, 2005. "Does corruption Grease or sand the wheels of growth?”, Public Choice,122, p.69

- Negin et all., 2010. "The Causal Relationship between Corruption and Poverty:A Panel Data Analysis", MPR Paper No:24871

- Mallik and Saha, 2012. "Growth and corruption: a complex relationship" In: 8th Annual Conference on Economic Growth and Development, Indian Statistical Institute, December 17-19, 2012, Indian Statistical Institute, New Delhi, India

- Rothstein and Holdberg, 2011. "Correlates of Corruption", The Quality of Government Institute (QOG) Workng Paper Series: 2011/12.

- Treisman, 2000. "The causes of corruption: a cross national study", Journal of International Economics,35, 1-22.

- Ugur and Dasgupta, 2011. "Evidence on the economic growth impacts of corruption in low-income countries and a beyond: a systematic review", EPPI-Centre, Social Science Research Unit, Institute of Education, University of London.

- UNDP,2007. Human Development Report 1997. Oxford University Press, New York

- Walter and Bettina, 2004. "Fighting Poverty and Corruption", Deutsche Gesellschaft für Technische Zusammenarbeit (GTZ) GmbH, Division:42. 